\title{
Role of education towards environmental management: case study Goma Junior High School DR Congo
}

\author{
by \\ Bernard Dechy \\ Uplift A Child of Congo \\ dechy@uplitachild.org
}

Mwisha Chinyhabuuma

Uplift A Child of Congo

dieumedechyh@gmail.com

submitted: 17-03-2021

revised: $24-03-2021$

accepted: 24-03-2021

\begin{abstract}
Abstrak
Penelitian ini bertujuan untuk mengetahui bagaimanakah aturan pendidikan di Sekolah Menengah Pertama Goma, untuk memahami sistem pengelolaan lingkungan, dan memahami hubungan antara pendidikan dan pengelolaan lingkungan di Sekolah Menengah Pertama Goma, DR Congo. Penelitian ini menggunakan metode campuran yaitu kuantitatif dan kualitatif. Pengumpulan data nonnumerik menggunakan pendekatan pengumpulan data kualitatif. Hasil penelitian menunjukkan bahwa pendidikan lingkungan membantu siswa meningkatkan taraf hidup, belajar melalui penanaman pohon, pengelolaan sampah, pengelolaan lingkungan yang baik di sekolah pertanian dan meningkatkan jumlah duta pengelolaan lingkungan di masyarakat. Sebagian besar siswa memiliki tingkat pemahaman yang moderat tentang masalah dan masalah lingkungan, sedangkan siswa lainnya memiliki pemahaman yang sangat baik atau baik dalam masalah pengelolaan lingkungan. Siswa berada pada pengetahuan dan pemahaman tingkat kontinum A ke A sedangkan daftar berada pada tingkat keterampilan pemecahan masalah dari tahap kontinum A ke A. Mahasiswa menjadi lebih bertanggung jawab dalam hal-hal yang berhubungan dengan pengelolaan lingkungan seperti penanaman pohon, menjaga lingkungan hidup tetap bersih dan menarik, serta mengelola sampah dengan baik.

Kata kunci: lingkungan, pendidikan, manajemen, sekolah
\end{abstract}

\begin{abstract}
Research aims to understand the rule of education in Goma Junior High School, to understand the level of environmental management, and relationship between education and environmental management. This research employed a mixed method which is quantitate and qualitative. Technique to gather non-numerical data, the researcher utilized a qualitative data collection approach. The results show that environmental education helps students improve their living, study through tree planting, waste management, good environmental management in the school farm and increase number of environmental management ambassadors in the community. The students have a moderate level of understanding on environmental issues and concerns while the rest of the students either have very good or good in understanding environmental management issues. Moreover, students are at the knowledge and understanding A to A continuum level while the list is in the problemsolving skills level of the A to A continuum phase. Students become more responsible in matters dealing with environmental management such as planting tree, keeping their living environment clean and attractive, and managing waste well.

Keywords: environment, education, management, school
\end{abstract}




\section{Introduction}

Education has the power to modify the society and present better knowledge to its populace. Education can stand as a proper solution to solve different sorts of problems exist in a community and, therefore, education has a prominent role to play to save the environment. The primary purpose of education when it comes to environmental protection is offering awareness to everyone in a society. Education can provide better awareness of a variety of ecological issues that take place day by day. Everyone in society including kids, youths, adults and mature people can understand and become aware of the various environmental issues if they get proper education on it. Education can give right knowledge on how natural environment functions, and how human beings can deal with behavior and ecosystems for sustainability (Subramanian et al., 2011). In the present day, a lot of people conduct an environmental awareness program in schools and societies. However, it is not yet established if the education programs provided in Goma primary Schools help in environmental management. This study therefore seeks to find out.

It has been defined that US environmental policy includes governmental actions at the federal, state and local level. It has been identified that US environmental education is characterized by an extraordinary variety of forms, directions and methodological approaches, deep penetration of the ideas of environmental ethics in the content of all the disciplines, extensive involvement of communities and, in particular, public non-governmental organizations in the process of forming US citizens' careful and responsible attitude to the environment. It has been stated that the system of US Environmental Education aims to provide a solution to such problems: to ensure citizens' close contact with the environment; to contribute to the forming of environmentally friendly styles of behavior and activities; to form a set of knowledge about the environment as a system of interconnected natural, economic and social factors; to involve students in solving local environmental problems. It has been found out that since 1970 Environmental Protection Agency has been operating in the USA. It has been mentioned that Environmental Protection Agency implements an environmental law by writing regulations and set national environmental standards. It has been indicated that Environmental Protection Agency has created the Office of Environmental Education so that national leadership may be provided and environmental literacy may be increased. It has been denoted that main goals of the Office of Environmental Education include design and implementation of curricula 
and training programs for environmental education for both pupils and adults; organization of seminars, conferences and discussions on urgent environmental issues; cooperation with state education departments and other agencies. Consequently, recommendations that may be used by native educators to improve the national system of environmental education have been presented.

In South Africa, Environmental Education policy in most cases is not an isolated entity or document. It is embedded within the school education and other policies. As in the case of South African Environmental Management Policy (Hamann et al., 2000). Environmental Education is addressed as capacity building. It also considers school education as one of the major vehicles to carry environmental awareness to society. Therefore, in most cases where governments look at Environmental Education and its practice, they are compelled to address that in terms of entire Educational Policy or curriculum at school level (Daskolia et al., 2012).

The Kenyan environmental policies, Beer (2016), and the White Paper on Environment and Development (1995) support the incorporation of environmental education into the national school curriculum. These policies propose that environmental education should be interdisciplinary and holistic in approach and should run across all school learning areas and disciplines. The policies further recognize the role of environmental education as a potential tool through which learners and the general public can engage themselves in critical issues related to environmental justice in Kenya.

In India, conservation education finds a place both in social studies and general science curricula and also in the applied side of agriculture. Physical and Commercial Geography, Economics, Agriculture and Biology are the main subjects in which a good amount of nature conservation is being taught at the high school stage, and as we go down to the lower stages, naturally simpler elements of nature conservation find a place in the curricula. The National Council of Educational Research and Training (NCERT) has been quite active and this has led to the formulation of curricula, which, to my mind, have not got distorted to the extent that Dr. Zim complained pertaining to his country. They have introduced a fairly good element of nature conservation education, weaving it into the general subjects rather than having pointed emphasis on nature conservation. 
In DR Congo, key issues such as climate change, biodiversity, disaster risk reduction, water, cultural diversity, sustainable urbanization and sustainable lifestyles are observed as entry points for promoting sustainable development practices through education (Snilstveit, 2016). All of these demands, advises policy-makers to integrate education for sustainable environmental development into education plans and curricula which is taught in schools to enable learners be able to maintain the environment through gaining knowledge in tree planting, afforestation, waste management and personal hygiene (UNDESA, 2015)

Government of DR Congo through its national education system emphasizes that education should empower each and every student to have concerns on his/her social and physical environment (Wilujeng et al., 2019). Its education policies from basic to higher education are formulated accordingly to implement Education for Sustainable Development (Muttarak \& Lutz, 2014). Education for Sustainable Development has been adopted globally as a consequence of the UN Decade for Education for Sustainable Development (DESD; 2005-2014) which has reshaped curricula worldwide (Subramanian et al., 2011). Education for Sustainable Development (ESD) has been launched as one of the key answers to dealing with sustainability. The underlying idea of ESD is to empower students with sustainability competences through a holistic interdisciplinary perspective of content and pluralistic learner-centered democratic teaching strategies. However, in spite of a global commitment to ESD as a teaching approach, there is very little empirical evidence in regard to North Kivu province within Congo for the extent to which ESD is implemented in classrooms, and the effects ESD has on student outcomes (such as their knowledge, attitudes, and behavior towards SD).

Therefore, this research was guided by the following questions: (1) What is the role of education in Goma Junior High School? (2) What is the level of environmental management in Goma Junior High School? (3) How is education related to environmental management? The present study intends to establish the role of education towards environmental management of Goma Junior High Schools in DR Congo.

\section{Methods}

The current study which was done in to establish the role of education towards environmental management of Goma Junior high schools in DR Congo utilized a field 
research designed with a descriptive-cross-sectional method. The cross-sectional descriptive guided research design was used to determine and describe the situation or the phenomenon as it was at the time of the study as recommended by (Zangirolami et al., 2018) Therefore, this design was suitable for this study as it provides both quantitative and qualitative descriptive regarding the study objectives. Thus, in order to gather numerical data, the researcher applied a quantitative data collection approach and in order to gather non-numerical data, the researcher applied a qualitative data collection approach. The purpose of this study was to explore the cultures and curricula that guide the instructional delivery and practices of the educators and their respective environmental education programs at Goma primary school in DR Congo. The program components were observed through a critical lens of the Awareness to Action continuum (A to A) strategies and Place-based Education (PBE) models. Totally, 29 interview subjects from Goma Junior High School including 1 head teacher, 1 deputy head teacher, 27 teachers. The 29 interview subjects will include teachers who have worked in the school for more than 5 years and have been involved in EE in some capacity. The researcher used interview method to provide qualitative data. The researcher has chosen this instrument because it is able to gather respondent's views and suggestions in regard to the study objectives.

\section{Results and Discussion}

Based on the interview guide carried out on the teachers of Goma, common responses were given expressing their qualitative views, feelings and opinions. For instance, qualitative showing ways in which EE program Inform Students and Help them understand how the Environment affects their Living and Studies it was realized that teachers in Goma use or apply or prefer giving relevant notes related to environmental education, consider giving students work related to environmental projects, use demonstration strategy in informing students about environmental management, like giving students assignments related to environmental management and prefer seminars for the students to learn about environmental management. Respondents' demographic characteristics in terms of gender, age, and job experience and education qualifications were assessed. 
Table 1.

Respondents Demographic Information

\begin{tabular}{|c|c|c|c|}
\hline & & Frequency & Percent \\
\hline Category of & Head Teacher & 1 & 3.4 \\
\hline \multirow[t]{4}{*}{ Respondents } & Deputy Head Teacher & 1 & 3.4 \\
\hline & 11th Grade Teachers & 12 & 41.4 \\
\hline & 12th Grade Teachers & 15 & 51.7 \\
\hline & & Frequency & Percent \\
\hline \multirow[t]{4}{*}{ Gender } & Male & 23 & 79.3 \\
\hline & Female & 6 & 20.7 \\
\hline & Total & 29 & 100.0 \\
\hline & & Frequency & Percent \\
\hline \multirow[t]{7}{*}{ Age } & 19-29 Years & 3 & 10.3 \\
\hline & 30-39 Years & 6 & 20.7 \\
\hline & 40-49 Years & 11 & 37.9 \\
\hline & 50-59 Years & 6 & 20.7 \\
\hline & 60 and Above Years & 3 & 10.3 \\
\hline & Total & 29 & 100.0 \\
\hline & & Frequency & Percent \\
\hline Job & 1-5 Years & 3 & 10.3 \\
\hline \multirow[t]{5}{*}{ Experience } & 6-10 Years & 6 & 20.7 \\
\hline & 11-15 Years & 14 & 48.3 \\
\hline & 16-20 Years & 6 & 20.7 \\
\hline & Total & 29 & 100.0 \\
\hline & & Frequency & Percent \\
\hline & Certificate & 3 & 10.3 \\
\hline \multirow[t]{4}{*}{ Qualification } & Diploma & 8 & 27.6 \\
\hline & Bachelor Degree & 14 & 48.3 \\
\hline & Master Degree and Above & 4 & 13.8 \\
\hline & Total & 29 & 100.0 \\
\hline
\end{tabular}

Table 1 of the study presents demographic information of the respondents in terms of gender and age job experience and education qualifications. Regarding the gender character of the respondents, it was realized that the school was represented by more male teachers $23(79 \%)$ compared to 6(21\%) female teachers. This could be attributed to the willingness of male teachers to participate in the study or their easy accessibility in the school than the female teachers. In terms of the age character of the study respondents, it was realized that teachers aged 40-49 years dominated the study, there was a similar presentation of 6(21\%) among teachers aged 30-39 years and 50-59 years as well as similar presentation of 3(10\%) among teachers aged 19-29 years and 60 years and above. This suggests that the school has well experienced teachers who were able to provide the required and relevant data for the study. 
Regarding the experience of the teacher respondents in terms of environmental education indicates that $14(48 \%)$ of the respondents were having 11-15 years of experience in teaching environmental education to the learners while few $3(10 \%)$ had the list experience of 1-5 years. This suggests that majority of the teachers in the school were well experienced in environmental education and hence provided the study with the relevant data. In terms of education qualifications, results show that 14(48\%) of the respondents had bachelor degree while 8(28\%) had diploma education qualification while 4(14\%) had master degree and above while few 3(10\%) had certificates. This suggests that the school has highly qualified teachers who are able to provide quality environmental education to the learners. Therefore, they provided relevant data for this study.

Table 2.

Showing ways EE program Inform Students and Help them understand how the Environment affects their Living and Studies.

\begin{tabular}{lcc}
\hline & Frequency & Percent \\
\hline Demonstration & 6 & 20.7 \\
Student environmental projects & 9 & 31.0 \\
Giving students environmental education assignments & 3 & 10.3 \\
Giving relevant notes to learners & 10 & 34.5 \\
Attendance and active participation of students in & 1 & 3.4 \\
seminars & & \\
\hline
\end{tabular}

Table. 2 shows different ways in which teachers in Goma use or apply in informing students to understand or in teaching students to understand how environment affects their living and studies. Findings indicates that majority 10(35\%) of teacher prefer giving relevant notes related to environmental education, $9(31 \%)$ consider giving students work related to environmental projects, 6(21\%) use demonstration strategy in informing students about environmental management, $3(10 \%)$ like giving students assignments related to environmental management and 1(3\%) prefer seminars for the students to learn about environmental management.

This shows that through environmental education, students gain knowledge through reading about environmental management, learn how to carry out environmental management projects, become good demonstrators to the community about environmental management and learn to contribute in environmental seminars. 
The results support the views of Smyth (2006) who explains that the concept of Environmental Education has defied universal definition by scholars in the field; this is so because there are some compounded views about what exactly is Environmental Education? The course Environmental Education is a new comer in the educational parlance; this is so because it came when other courses had already taken their roots in human history. Environmental Education (EE) therefore can be defined as an organized effort geared towards teaching about the functioning of natural environment, particularly, how humans and other life forms interact with the environment and its resources in the ecosystems in order to live sustainably.

Table 3.

Showing How the EE program prepares students to make pro-environmental decisions in the school

\begin{tabular}{lcc}
\hline & Frequency & \% \\
\hline Increased tree planting efforts by students in the school & 13 & 44.8 \\
Better waste management efforts by the students & 3 & 10.3 \\
Good environmental management in the school farm & 2 & 6.9 \\
increased number of environmental management & 11 & 37.9 \\
ambassadors from the school & & \\
Total & 29 & 100.0 \\
\hline
\end{tabular}

Table 3 presents empirical information on how EE program prepares students to make pro-environmental decisions in the school in Goma Junior High School whereby the results indicates that Environmental Education helps students to improve their living and studies through tree planting at $44.8 \%$, through better waste management at 10.3\%, good environmental management in the school farm at $6.9 \%$ and increased number of environmental management ambassadors in the community at $37.9 \%$. The findings imply that education prepares students in tree planting, making them good environmental managers in the school, community and their families, gives learners waste management skills as well as provides them with skills and knowledge about environmentally friendly farming methods.

The findings are supported by the views of Disinger (2001) Environmental Education is a process that allows individuals to explore environmental issues in class, through seminars, demonstrations and practical sessions, engage in problem solving, and act to improve the environment; as a result, therefore, individuals develop a deeper understanding of environmental issues and have the skills to make informed 
and responsible decisions. So, education on environmental issues is essential today since it lets people build up skills, foster a dedication to take steps individually and communally to maintain and enhance the environment (UNESCO, 2014).

Objective two of the study was to find out the level of environmental management in Goma Junior High School 3. Variable investigated was level of environmental management. And the empirical results are presented in Table 4.3 of the study.

Table 4.

How would you describe current student connections with and understanding of environmental issues and concerns?

\begin{tabular}{lcc}
\hline & Frequency & Percent \\
\hline Very good & 2 & 6.9 \\
Good & 8 & 27.6 \\
Moderate & 12 & 41.4 \\
Poor & 6 & 20.7 \\
Very Poor & 1 & 3.4 \\
Total & 29 & 100.0 \\
\hline
\end{tabular}

Table graph 3 presents empirical information on student connections with and understanding of environmental issues and concerns and findings shows that majority of the students have a moderate level 12(41\%) level of understanding environmental issues and concerns while $10(34.5 \%)$ of the students were either very good or good with $7(24.1 \%)$ being poor or very poor in understanding environmental management issues. This implies that there is a moderate level in environmental management Goma Junior High School and more efforts are required to empower students in matters related to environmental management through provision of environmental education.

Carter (2006) explains that when students are provided with environmental education, the level of environmental management in their area tends to improve since they learn more about tree planting, waste management and application of better farming strategies as well as keeping the school compound clean and attractive. Thus, according to Carter (2006), the primary purpose of education when it comes to environmental protection is offering awareness to everyone in a society. Education can provide better awareness of a variety of ecological issues that take place day by day. Everyone in society including kids, youths, adults and mature people can understand 
and become aware of the various environmental issues if they get proper education on it. Education can give right knowledge on how natural environment functions, and how human beings can deal with behavior and ecosystems for sustainability. In the present day, a lot of people conduct an environmental awareness program in schools and societies. Objective three of the study was to come up with measures to improve environmental management in Goma Junior High School 3. Results are presented in this sub-section of the study.

Table 5 .

Showing what needs to be added to or changed, either in this EE program or to school or home-based EE, to motivate students toward pro-environmental behaviors and action

\begin{tabular}{llccc}
\hline & & Frequency & Percent \\
\hline $\begin{array}{l}\text { Reward students for the efforts they do in } \\
\text { environmental management }\end{array}$ & 12 & 41.4 \\
Make students own their projects & & 11 & 37.9 \\
More practical sessions to be introduced to the school & 6 & 20.7 \\
Total & 29 & 100.0 \\
\hline
\end{tabular}

Table 4 presents qualitative data on what needs to be added to or changed, either in this EE program or to school or home-based EE, to motivate students toward pro-environmental behaviors and action. Results indicates that the respondents suggested for reward to students for their efforts in environmental management $12(41.4 \%)$ both in school as well as at the community level whereby presets and gifts as well as recognition be given to students who participate in tree planting, waste management or tend to be performing well in environmental education classes at school. Also, the respondents recommended for the school to encourage students do environmental projects and in the process make the students own their projects $11(37.9 \%)$ as this will make them more responsible and highly encouraged to do better in tree planting, waste management and environmentally friendly farming projects and this will make students do this kind of projects for fun and self-drive in future. In addition, the teacher respondents suggested for a practical teaching method to be introduced in school $6(20.7 \%)$ whereby teachers need to come out and provide practical sessions to students, there should be more environmental management related clubs created among students, more workshops and seminars to be carried out between schools and other institutions mandated in environmental management. The results are in line with the views of Mattoo and Subramanian (2013) who explains that 
in higher education, various environmental courses for undergraduates, such as natural resources management, are provided. At some universities, such as the University of Congo and Bogor Agricultural University, graduate courses on the environment, including EE, are also offered. These universities often make joint efforts with NGOs in providing environmental education to the public for example Bogor Agricultural University and Gadjah Mada University. Teacher's colleges also try to incorporate environmental elements in their courses.

Table 6.

Expectation on what students, environment and the EE program should be toward environmental management in Goma Junior High School

\begin{tabular}{|c|c|c|}
\hline & Frequency & Percentage \\
\hline $\begin{array}{l}\text { Government to fund schools in carrying out } \\
\text { environmental management programs }\end{array}$ & 5 & 17.2 \\
\hline $\begin{array}{l}\text { Students to develop a positive attitude towards } \\
\text { environmental education and actively } \\
\text { participate in practical environmental } \\
\text { management programs }\end{array}$ & 10 & 34.5 \\
\hline $\begin{array}{l}\text { Instructors to apply suitable and more effective } \\
\text { teaching methods when undertaking EE }\end{array}$ & 9 & 31.0 \\
\hline $\begin{array}{l}\text { The environment should always be friendly, } \\
\text { attractive, and conducive to the livelihood of the } \\
\text { people }\end{array}$ & 5 & 17.2 \\
\hline Total & 29 & 100.0 \\
\hline
\end{tabular}

Table 5 presents empirical data on what students; environment and the EE program should be towards environmental management in Goma Junior High School. This shows that teachers recommended for the government to fund schools in carrying out environmental management programs $5(17.2 \%)$ in which the funds can ensure that the school has waste management facilities, tree planting programs, facilitates environmental management clubs and rewards students who put their efforts in environmental management projects. In addition, the teacher respondents recommended that students should develop a positive attitude towards environmental education and actively participate in practical environmental management programs $10(34.5 \%)$ as this will ensure that students join environmental management clubs, attend workshops and environmental seminars willingly and actively. In addition, it was recommended that the instructors should apply suitable and more effective teaching methods when undertaking EE $9(31 \%)$ like demonstration, practical projects 
and experimental which can make students participate in environmental management activities. Finally, the environment should always be friendly, attractive, and conducive to the livelihood of the people 5(17.2\%).

The results support the views of UNDESA (2015) who explains that making a real investment in environmental education is very important since we live in an epoch where more and more people are disconnected from nature and unaware of critical environmental issues. Education is a tool for self-empowerment because it enables us to take serious and effective action. Environmental education leads people to be future conservation leaders and encourage them to take serious and effective action towards critical environmental issues of the day.

\section{Conclusion}

Through education, students learn more in terms of class notes, demonstration, assignments, practical strategies for environmental management in Goma Junior High School which helps students to improve their living and studies through tree planting, better waste management strategies, and making many students environmental management ambassadors in the community.

There is a moderate level in environmental management in Goma Junior High School whereby majority of the students have a moderate level of understanding environmental issues and concerns. It was realized that majority of the students were in the knowledge and understanding A to A continuum level. However, students become more responsible in matters related to environmental management such as tree planting, keeping their living environment clean and attractive, managing waste well and informing other people both in school and outside the school on how to manage the environment.

On measures to improve environmental management in Goma Junior High School, teacher respondents suggested for reward to students for their efforts in environmental management, the school to encourage students to do environmental projects and in the process make the students own their projects. In addition, practical teaching method should be introduced in school whereby teachers need to come out and provide practical sessions to students, there should be more environmental management related clubs created among students, more workshops and seminars to be carried out between schools and other institutions mandated in environmental management. 
In addition, the government should fund schools in carrying out environmental management programs, students should develop a positive attitude towards environmental education and actively participate in practical environmental management programs, and teachers/instructors should apply suitable and more effective teaching methods when undertaking EE like demonstration, practical projects and experimental which can make students participate in environmental management activities.

\section{References}

Ardeshana, B. (2015). The Role of Education in Saving Environment. 2(2), 48-51.

Ardoin, N. M., Bowers, A. W., \& Gaillard, E. (2020). Environmental education outcomes for conservation: a systematic review. Biological Conservation, 241 (10822), 1-14. https://doi.org/10.1016/j.biocon.2019.108224

Bangay, C. (2016). Protecting the future: The role of school education in sustainable development - an Indian case study. International Journal of Development Education and Global Learning, 8(1), 5-19. https://doi.org/10.18546/ijdegl.8.1.02

Beames, S. (2017). Innovation and outdoor education. Journal of Outdoor and Environmental Education, 2O(1), 2-6. https://doi.org/10.1007/BF03400997

Eneji, C.-V. O., Akpo, D. M., \& Etim, E. A. (2017). Historical Groundwork for Environmental Education (Fundamentals and Foundation of Environmental Education). International Journal of Continuing Education and Development Studies (Ijceds), 3(May), 110-123.

Fraser, B. J. (2015). Environments for Education. In International Encyclopedia of the Social \& Behavioral Sciences: Second Edition (pp. 820-823). Elsevier Inc. https://doi.org/10.1016/B978-0-08-097086-8.92077-4

Heale, R., \& Twycross, A. (2015). Validity and reliability in quantitative studies. Evidence-Based Nursing, 18(3), 66-67. https://doi.org/10.1136/eb-2015102129

Hume, T., \& Barry, J. (2015). Environmental Education and Education for Sustainable Development. In International Encyclopedia of the Social \& Behavioral Sciences: Second Edition (pp. 733-739). Elsevier Inc. https://doi.org/10.1016/B978-0-08-097086-8.91081-X

Hungerford, H. R., \& Volk, T. L. (2013). Changing Learner Behavior Through Environmental Education. The Journal of Environmental Education, 21(3), 821. https://doi.org/10.1080/o0958964.1990.10753743

Mattoo and Subramanian. (2014). Stockholm Environment Institute Report Part Title : REFERENCES Report Title : Governing the transition away from fossil fuels : Report Subtitle: The role of international institutions Report Author ( s): Harro van Asselt Published by: Stockholm Environ. https://doi.org/10.1073/pnas.1107409108.Dubash

McBeth, W., \& Volk, T. (2011). The national environmental literacy project: A baseline study of middle grade students in the United States. Journal of Environmental 
Education, 41(1), 55-67. https://doi.org/10.1080/o0958960903210031

Moore, F. (2017). Qualitative Design Options for a Study. March. https://doi.org/10.13140/RG.2.2.21925.29925

Moore, H. L. (2015). Global Prosperity and Sustainable Development Goals. Journal of International Development, 27(6), 801-815. https://doi.org/10.1002/jid.3114

Muttarak, R., \& Lutz, W. (2014). Is education a key to reducing vulnerability to natural disasters and hence unavoidable climate change. Ecology and Society. 19, (1). The Resilience Alliance. https://doi.org/10.5751/ES-06476-190142 